\title{
Notaris Law Protection Under The Civil Law In Law Number 2 Year 2014 Concerning Amendment To Law Number 30 Year 2004 Regarding Notary Position
}

\author{
Farah $^{1}$, Dewi Sukmaningsih ${ }^{2}$ and Gunarto ${ }^{3}$
}

Abstract. Legal protection should be provided to all persons, including Notaries. Legal protection of a Notary can be done through a process, namely: the use of the rights or obligations of non-compliance of Notaries and the calling of a Notary by the investigator, public prosecutor and judge shall be done by obtaining Notary Honorary Council (MKN) approval.

The purpose of the research was to analyze the implementation of legal protection to the notary and to know the obstacles as well as the solution in Law number 2 year 2014 on the amendment of Law No. 30 year 2004.

This study used a juridical-normative approach obtained from primary data and secondary data analysis techniques and used qualitative data analysis.

The results of the study indicated that the legal forms of legal protection to the Notary under the UUJN Law are: 1 Regulation on the obligation of non-disclosure and right of non-disclosure (Article 4 paragraph 2 and Article 16 paragraph 1), 2) Fingerprint attachment in minuta deed (Article 16 paragraph (1) c), 3) Approval of the Notary Public Honor Council (Article 66 paragraph 1), 4) Protection of Indonesian Notary Association (Article 67 paragraph) 5) The obstacle is the absence of change of the Implementing Law of UUJN, the absence of Notary Honorary Council, and the lack of socialization. Legal protection for a Notary to the deeds he made regarding the accountability of a civil notary is the existence of an independent Notary Publicity Council. The government should provide special training to the notary to minimize adverse effects.

Keywords: Notary, Legal Protection, UUJN

\section{Introduction}

The position of a Notary is not placed in the judiciary, executive or judicial institution because the Notary is expected to have a neutral position. The position of a Notary is held or its presence is desirable by the rule of law with a view to assisting and serving the community in need of authentic written evidence of circumstances, events or legal acts.

Currently, Law Number 30 Year 2004 regarding Position of Notary has been renewed by Law Number 2 Year 2014 concerning Notary Public Definition. It is as referred to in Article 1 number 1 UUJNP, the notary is General Official authorized to make authentic deed and have other authority referred to in this law or under any other law. In accordance with its authority, a Notary is authorized to produce an authentic deed as provided for in Article 15 paragraphs (1), (2) and (3) of Law Number 2 Year 2014.

The strength attached to the authentic deed is perfect (volledig bewijskracht) and binding (bindende bewijskracht), which means that if the authentic Deed is filed qualified formally and materially and the defendant's stated evidence does not diminish its existence, and binding (volledig en bindende bewijskracht). Thus, the truth of the contents and statements contained therein becomes perfect and binding to the parties concerning the so-called deed. Perfect and binding to the judge so that the judge should make it a perfect

1 Student of Master Program in , Faculty of Law, Universitas Islam Sultan Agung email farah01@gmail.com

2 Students of Master of Law, Faculty of Law, Universitas Islam Sultan Agung email dewiadams99@gmail.com

${ }^{3}$ Professor of Faculty of Law UNISSULA 
and sufficient fact base to take a decision on the settlement of the disputed case. ${ }^{4}$

The responsibilities of a Notary as a Public Official include the responsibility of the Notary profession itself relating to the deed, such as: First, the responsibility of the Notary in a civil case for the deeds made. Second, the responsibility of the Notary in a criminal manner on the deed he made. Third, the Notary's responsibility is administratively on the deed he made. Administrative sanctions based on Law no. 2 Year 2014 mentions that there are 5 (five) sanctions. The criteria of the deed under the hand are the Content (in) certain Articles which directly affirm if the Notary has committed an offense. Then the related deed according to Article 84 of Notary Law is null and void deed. ${ }^{5}$

Based on this matter, the notary as a public official must be protected in carrying out his position. Therefore, the authors examined this research with the title "Legal Protection to the Notary under the Civil Law in Law Number 2 Year 2014 on Amendment to Law Number 30 Year 2004 About Notary Position"

The formulation of the problem in this research is how the implementation of legal protection to the notary under the civil law in Law Number 2 Year 2014 About Amendment to Law Number 30 year 2004 on the position of notary? How is the obstacle and solution of legal protection to notary under the civil law in Law Number 2 Year 2014 about the change of law number 30 year 2004 about notary's position?

\section{Research methods}

This type of research is normative legal research. The conceptual approach in this study referred to legal principles. This study used secondary data source types, namely: data supporting information or supporting the completeness of primary data obtained from libraries and collections of the authors, it was conducted by library study or literature. The legal substance used in this research was obtained from the search through the literature study. Data were obtained, analyzed by using normative analysis. The collected data were poured in the form of logical and systematic description, then analyzed to get clarity of problem solving, then deductively deduced conclusions, that is from general to specific.

\section{Discussion}

\subsection{The Forms of Legal Protection to the Notary under the Civil Law In Law Number 2 Year 2014 About Amendment to Law Number 30 Year 2004 About Position of Notary}

Legal protection provided by the state rests on human rights guarantees and puts forward the wetmattigheid or governmental principle is based on law. Thus, in order to achieve legal protection, legal products become the main pillar as protection. In addition, it also takes the spirit of law enforcement officers to seriously implement the duty in accordance with the applicable law

Currently, Law Number 30 Year 2004 regarding Notary Public Offices has been renewed by Law Number 2 Year 2014 regarding Notary Position (UUJNP). Notary is as a general official who runs the profession in providing legal services to the community, needs to get legal protection and guarantees to achieve legal certainty. The guarantee of protection and guarantee to achieve legal certainty in the implementation of the duties of a Notary has been regulated in Law Number 30 year 2004 concerning Notary Position. However, some

4 Christin Sasauw, Tinjauan Yuridis Tentang Kekuatan Mengikat Suatu Akta Notaris Jurnal Lex Privatum Vol. III/No. 12015 p.100.

5 Habib Adjie 2008 Sanksi Perdata dan Administrasi Terhadap Notaris Sebagai Pejabat Publik Refika Aditama Bandung p. 94. 
provisions in the law are no longer compatible with the development of law and the needs of the community, so that it needs to be amended. Law number 2 year 2014 is also intended to further affirm and strengthen the tasks, functions and authorities of Notary as an officer to run the public services, as well as synchronization with other laws. ${ }^{6}$

The responsibility of a Notary acknowledges the principle based on fault of liability. In making authentic deed, the Notary shall be liable if the deeds thereof are made by mistake or willful violation by Notary. Conversely, if the element of error or violation occurs from the parties facing the objection, as long as the Notary carries out his authority according to the regulations, the Notary cannot be asked his/her accountable. Since the Notary only records what is conveyed by the parties to be included in the deed. False statements submitted by the parties shall be the responsibility of the parties ${ }^{7}$. The civil notary's responsibility to the deeds made, the deed made by the notary is civil deed. It means it is about the engagement made by two or more parties, although it is possible the deed is made unilaterally (its only strengthening). The nature and principles embraced by the law of engagement, in particular to the deed made under an agreement, the law is only possible and may be changed or replaced or declared invalid, only by those who make it, ie the agreement of both parties as set forth in an authentic deed. If an error made by a Notary can be proven, the Notary can be subjected to sanctions in the form of a threat as determined by law. ${ }^{8}$

Notary Law is a legal product intended to provide legal certainty and protection for the Notary in performing his profession as an official of authentic deed maker. Therefore, in the UUJN contains a rule of law, one of which is a form of legal protection for a Notary. The forms of legal protection to the Notary according to Law no. 2 Year 2014 are:

- Provisions governing the obligation to disclosure and right of non-disclosure the Notary's rights listed in: Article 4 paragraph (2), Article 16 paragraph (1) letter $f$ and Article 54. Habib Ajie refers to the right of non-disclosure as "the obligation of noncompliance (verschoningsplicht) Notary". Habib Ajie explained that one part of the Notary's pledge is that the Notary will keep the content of the deeds and statements obtained in the execution of Notary in accordance with Article 4 paragraph (2) and Article 16 paragraph (1) subparagraph $f$ UUJN. Notary has the obligation to conceal everything concerning the deeds he made and all information obtained for deeds in accordance with the oath/pledge of office, other than the law of deciding otherwise ${ }^{9}$. In the case of giving a testimony, a notary cannot disclose the deed made in part or in whole to another party. This is in accordance with Article 54 of the UUJN because as a trusted person, the notary is obliged to keep all the things notified to him in his position as a notary, even if there is a part that is not included in the deed, and has been deemed to represent a notary in a trial. So that the deed is made by or before a notary is a proof that has perfect proof power. ${ }^{10}$

\footnotetext{
${ }^{6}$ Law Number 2 of 2014 concerning Amendments to Law Number 30 of 2004 concerning Notary Position p. 32

7 Andi Mamminanga Pelaksanaan Kewenangan Majelis Pengawas Notaris Daerah dalam Pelaksanaan Tugas Jabatan Notaris berdasarkan UUJN Tesis Fakultas Hukum Universitas Gajah Mada Yogyakarta 2008 p. 32.

${ }^{8}$ Kunni Afifah 2017 Tanggung Jawab dan Perlindungan Hukum bagi Notaris secara Perdata Terhadap Akta yang Dibuatnya Jurnal Universitas Islam Indonesia. p. 154

${ }^{9}$ Habib Adjie 2008 Sanksi Perdata dan Administrasi Terhadap Notaris Sebagai Pejabat Publik Refika Aditama Bandung p. 89

${ }^{10}$ Pricilia Yuliana Kambey 2013 Notaris sebagai Saksi dalam Suatu Persidangan. Jurnal Lex et Societatis Vol. I/No.2/Apr-Jun/2013.
} 
- Fixed the fingerprint in the minuta deed as stipulated in Article 16 paragraph (1) letter c which states that "in the conduct his position, the Notary must attach letters, documents and fingerprints to the Minuta deed". This is the duty of the Notary Supervisory Board to supervise when checking the completeness of supporting documents for making minuta deed. The fingerprint function is here to further strengthen the evidence. Thus, his arrangement of fingerprints is to corroborate the problem of proof. It is expected that attaching fingerprints provides more legal protection for Notaries.

- Notary Honorary Council Approval

Legal protection to the Notary in carrying out his/her duties and authority for the realization of the service function and the achievement of legal certainty in providing services to the public, has been regulated and set forth in Article 66 UUJNP. In Law No. 2 Year 2014 the provisions of paragraph (1) of Article 66 are amended and added 2 (two) paragraphs, namely paragraph (3) and paragraph (4) so that Article 66 reads as follows:

- For the benefit of the judicial process, investigators, public prosecutors, or judges with the approval of the Notary Honorary Board are authorized to:

- take copies of Minuta Deed and/or letters attached to Minutes of Deed or Notary Protocol in the Notary's depository; and

- call a Notary to attend the examination relating to the Notary Deed or Protocol which is in the Notary's deposit.

- The taking of copy of Minuta Deed or the letters as meant in sub-article (1) letter a, shall be made the official report.

- Notary Honorary Council within 30 (thirty) working days at the latest from the date of receipt of the letter of application for approval as referred in paragraph (1) shall be obligated to provide an answer to accept or reject the request for approval.

- In the case where the honorary board of Notary does not provide an answer within the period referred to in paragraph (3), the honorary board shall be deemed to receive the request for approval.

The provision of Article 66 Paragraph (1) of the UUJN of Amendment mentions that for the purposes of the judicial process, the investigator, the persecutor or the judge can take action with the approval of the Notary Honorary Council. The article clearly specifies the institution which gives consent for its calling and/or the taking of Minutes of Deed and/or the letters attached to Minutes of Deed or Notary Protocol in the Notary's depository. However, Article 66A paragraph 3 states that regarding this Notary Honorary Council will be regulated by Ministerial Regulation. However, until now the regulation does not yet exist. Under the provisions of Article 66A, the process of granting approval from Notary Honorary Council must perform inspection in advance. Examination conducted in accordance with the provisions of Article 70 Sub-Article a UUJN of Amendment, conducting a hearing in advance to examine the alleged violation committed by a notary. After the examination is done, the final result of the Notary Honorary Council examination is set forth in the form of a Letter of Decision which gives approval or rejection to the request of the Investigator, Prosecutor or Judge.

- Protection to the Notary as a member of Indonesian Notary Association

The provisions concerning notary organization are stipulated in Article 82 Paragraph (2) of the UUJN of Amendment which states that "Organization of Notary as referred to in paragraph (1) is Indonesian Notary Association." Legal protection of members is laid in the framework of commitment to the value of togetherness among peers and commitment to the nobility of the Notary as Public Official. As the core purpose of the establishment of the association, INA (Indonesian Notary Association) guarantees the 
protection of Notaries in relation to their profession and position as public officials. Therefore, to provide legal protection for its members, INA also cooperates with the police institution through a memorandum of understanding between INA and POLRI (Indonesian Police) Number: 01/MoU/PP-INI/V/2006 which essentially regulates the guidance and professionalism in the field of law. It is a legal protection for the notary in connection with the secret of office as a profession based on trust. The above memorandum of understanding is a procedure that must be carried out if the notary is called or examined by the police.

- Supervision of Notary Profession Practice

Law enforcement must be done in the presence of a system of supervision over legal practices to avoid any abuse by legal practitioners. The removal of the phrase "with the consent" in Article 66 of the UUJN may be one of the impetus for the Notary organization (Ikatan Notaris Indonesia/INI) and the Notary Supervisory Council to conduct more intensive supervision to the Notary in its shade. Supervision of Notary under Article 67 Paragraph (5) Amendment of UUJN covering: Supervision on Notary's behavior in UUJN Changes, it can be seen in Article 9 paragraph (1) letter c and Article 12 letter c. The Notary's behavior can be categorized as misconduct and acts that undermine the honor and dignity of the Notary's office, such as gambling, drinking, drug abuse and so on.

Legal protection to the Notary in the process of law enforcement in court can be done through the process, namely: the use of rights or obligations of non-compliance of Notary Public as well as invitation of Notary by investigator, public prosecutor and judge, there law enforcer must get approval from Notary Honorary Council. This is as regulated in Article 66 paragraph (1) UUJN. Another form of legal protection is in the form of supervision, attaching fingerprints to the legal certificate and legal protection of the Notary Main Organization (INI). ${ }^{11}$

\section{Obstacles in the Implementation of Legal Protection to the Notary Public under Civil Law No. 2 of 2014 about Amendment To Law Number 30 Year 2004 About Position of Notary}

The enactment of the UUJN of the amendment in its implementation raises barriers which include:

- The absence of UUJN Implementing Regulations Amendment

Constraints in this rule of law is the lack of the implementation of UUJN regulations of change as mandated in Article 91B UUJN amendment, so the mechanism of investigation of Notary still refers to the old UUJN. The previous UUJN has been rectified by the Constitutional Court Decision Number 49/PUU-X/2013 revoking Article 66 paragraph (1), especially on the phrase about the obligation to get approval from the Regional Supervisory Board (MPD). This in turn is also related to the nonimplementation of Article 14 paragraph (1) of Regulation of the Minister of Justice and Human Rights No. M.03HT.0310 of 2007 which regulates Regional Supervisory Board. In addition, in the UUJN of Change, there are several provisions set forth in the new article which may lead to multiple interpretations in practice in the field, because the implementation rules have not yet been established.

- Role of INA (Indonesian Notary Association) to socialize about UUJN Changes in certain areas are lacking

Socialization activities are important to do considering the need for a deep understanding of some changes of UUJN that have been enacted since 2014. Basically,

${ }^{11}$ Ibid. P.91 
the socialization of UUJN changes is done as a form of unification of views in practice for the notary public. However, the role of INA to conduct socialization activities on UUJN changes in certain areas is lacking.

\section{Conclusion}

- Forms of legal protection to the Notary according to UUJN are: concerning the obligation of renunciation and the right of non-disclosure of Notary listed in Article 4 paragraph (2), Article 16 paragraph (1) letter $f$ and Article 54 paragraph 2), attaching fingerprints in minuta deed (Article 16 paragraph (1) letter c), Notary Honorary Council Approval, Protection of Notaries as a member of the Indonesian Notary Association (Article 82 paragraph 2 UUJN Amendment), Supervision of Notary profession practices (Article 67 paragraph 5 UUJN Amendment). The form of legal protection for a Notary to the deeds he made concerning the accountability of a notary publicly is the existence of an independent Notary Honorary Council, in which case the existence of Notary Honorary Council is not a subdivision of the government that appointed it. Notary Honorary Council in exercising its authority to issue a decision is not influenced by other parties or institutions, so in this case the decision produced by Notary Honorary Council is inviolable.

- Obstacles in the implementation of legal protection to the Notaries According to the UUJN is not yet established Act on the Amendment of the UUJN, the establishment of the Notary Honorary Council (MKN), and the role of INA to disseminate information on UUJN Amendments in certain regions is still lack. To overcome these obstacles, the government should immediately formulate the UUJN Implementation Act so as not to generate multi-interpretation.

The government should provide special training to notaries on a regular basis to minimize adverse impacts that harm the parties in making authentic deeds and take firm action against notaries anytime they are suspected of violating the notary profession's code of ethics that can be qualified as criminal suspects.

\section{References}

[1] Andi Mamminanga 2008 Pelaksanaan Kewenangan Majelis Pengawas Notaris Daerah dalam Pelaksanaan Tugas Jabatan Notaris berdasarkan UUJN Tesis Fakultas Hukum Universitas Gajah Mada Yogyakarta

[2] Christin Sasauw, Tinjauan Yuridis Tentang Kekuatan Mengikat Suatu Akta Notaris Jurnal Lex Privatum Vol. III/No. 12015.

[3] Departemen Pendidikan Nasional 2008 Kamus Besar Bahasa Indonesia Gramedia Pustaka Utama Jakarta

[4] Habib Adjie 2008 Sanksi Perdata dan Administrasi Terhadap Notaris Sebagai Pejabat Publik Refika Aditama Bandung

[5] Kunni Afifah 2017 Tanggung Jawab dan Perlindungan Hukum bagi Notaris secara Perdata Terhadap Akta yang Dibuatnya Jurnal Universitas Islam Indonesia

[6] Pricilia Yuliana Kambey 2013 Notaris sebagai Saksi dalam Suatu Persidangan. Jurnal Lex et Societatis Vol. I/No.2/Apr-Jun/2013

[7] Sjaifurrachman 2011 Aspek Pertanggungjawaban Notaris dalam Pembuatan Akta Mandar Maju Bandung

[8] Undang-Undang Nomor 2 Tahun 2014 Tentang Perubahan Atas Undang-Undang Nomor 30 Tahun 2004 Tentang Jabatan Notaris

[9] Undang-Undang Nomor 30 Tahun 2004 Tentang Jabatan Notaris 